\title{
Historein
}

Vol 1 (1999)

\section{History and Semiotics}

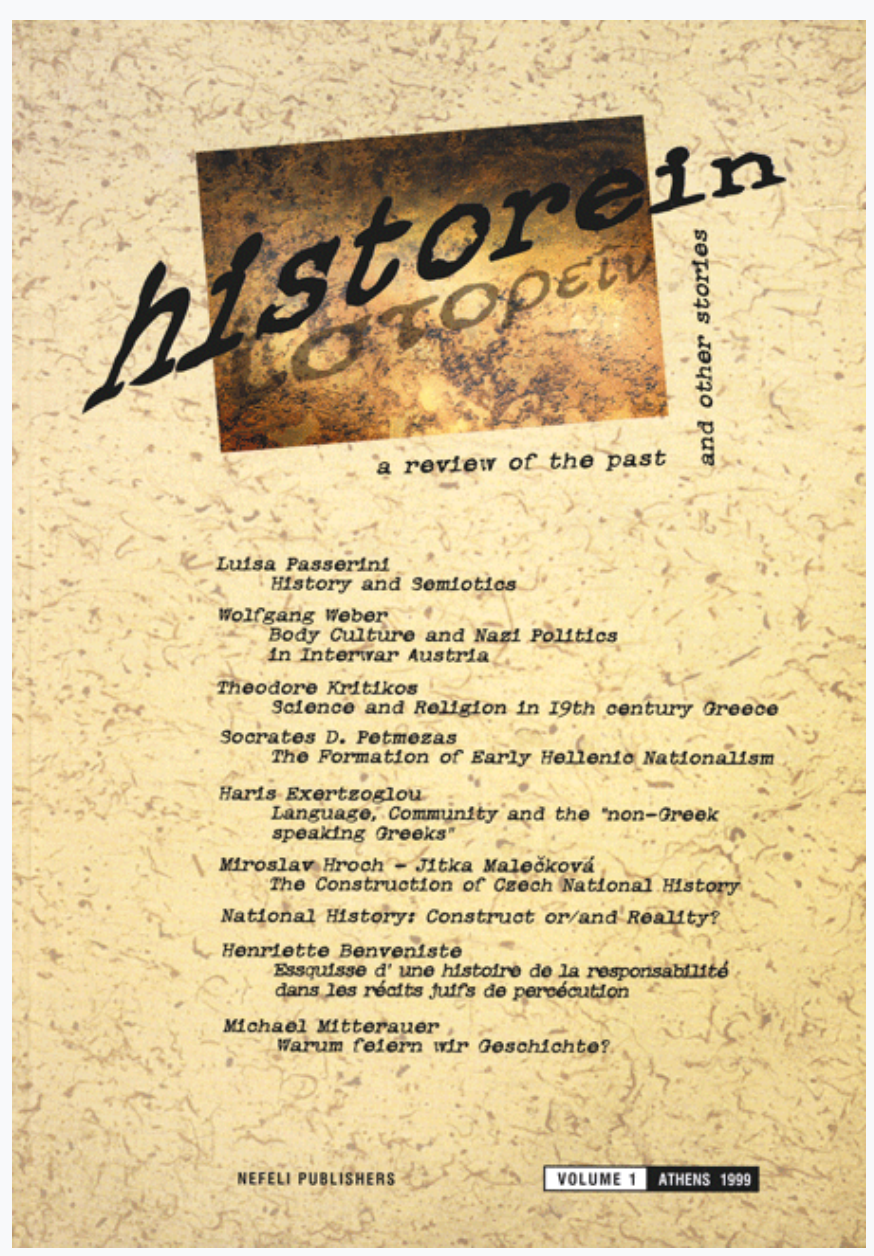

\section{Shifting Boundaries: Language, Community and the "non-Greek speaking Greeks"}

Haris Exertzoglou

doi: $\underline{10.12681 / \text { historein.127 }}$

\section{Copyright @ 2012, Haris Exertzoglou}

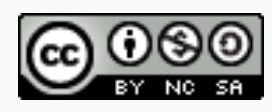

This work is licensed under a Creative Commons Attribution-NonCommercialShareAlike 4.0.

\section{To cite this article:}

Exertzoglou, H. (2000). Shifting Boundaries: Language, Community and the "non-Greek speaking Greeks". Historein, 1, 75-92. https://doi.org/10.12681/historein.127 


\section{Shifting}

\section{boundaries:}

\section{language,}

community

\section{and the}

"non-Greek-

\section{speaking \\ Greeks"}

Haris Exertzoglou
I. Recent studies on nation and nationalism have raised important questions about the nature of nation as a particular kind of community. This highly suggestive literature focuses on the institutional, political and technical aspects of nation building and looks into the social transformations and modernising state policies which paved the ground for the rise of nations in the modern era. In the same vein nationalism is treated as an ideology or form of politics that is specifically modern. ${ }^{1}$

In this context, the centrality of the concept of the nation as a creation of modernity is contrasted to representations of the nation as a transhistorical subject, common in nationalist literature. Thus, a distinction has been established between critical conceptualisations of the nation as a modern construct and its ideology bound, nationalist counterparts. This distinction, however, typically leads to the disregard of nationalist discourses and rhetoric as valid objects of historical analysis. ${ }^{2}$ Furthermore, it tends to obscure the discursive practices whereby specific cultural features are privileged within particular nationalist discourses, their interplay, as well as the way specific groups are conceptually classified within particular communities. These remarks are not intended as a rejection of the thesis that holds the nation as a product of modernity. My point is that particular attention should be paid to the discourses which shaped nations as a meaningful reality so as to grasp the concrete effectivity of nationalist representations of community. If we think of national discourses as simply rhetorical tropes devoid of any effect, ${ }^{3}$ their working as meaning production systems is entirely lost.

I take nationalist discourse as a modern, authoritative system of representation that connects things according to specific 


\section{$=\pi_{1}^{2}$}

matter, is embedded in a power/knowledge nexus. ${ }^{4}$ It always operates at an institutional level, be it the academy, state institutions, political parties directly associated with national states, or scientific, literary, historical and political associations operating in other state formations. By privileging a conception of the nation as the ordering principle of reality, nationalist discourse forged a new thinkable order of things whereby cultural and social experience, notions of time, space and community assumed a novel significance. Here a specific relation between discourse and reality is operative. Nationalist discourse purports to express a preconstituted national entity which is accorded an objective pre- and extra-discursive status, an entity whose values, qualities and dispositions are deemed recoverable and knowable because real. In fact, rather than expressing an already existing community, nationalist discourse constitutes it by signifying aspects of experience as objective signs of national existence. Thus, the important thing is not raw experience but its particular interpretation, not reality as such but the meaning assigned to it. This could happen when particular, that is selected, questions are asked in relation to a specific vision of the community in mind by specific groups of intellectuals and bureaucrats who present themselves as expressing "national interests". In addressing historical, linguistic and cultural issues necessary to produce truth claims about the national community in view, this discourse shapes the form and direction of cognitive fields such as history, linguistics and ethnography. As such, nationalist discourse not only constructs its own symbolic realm where everything is measured against a nationally meaningful order of things. It also develops the cognitive tools to control and corroborate it. This link between nationalist discourse and knowledge entails neither the view that this discourse simply subjected aspects of knowledge under its ideological hold and therefore those cognitive fields influenced by discourse should not be counted as true, scientific knowledge, nor that discourse by rectifying its errors and classifying its formulations, through its association to these cognitive fields, undid its relations with ideology. In the first place any clear distinction between ideology and knowledge is impossible. It is crucial to understand how nationalist discourse controlled meaning and imposed its own representations of reality through its connection with the aforementioned cognitive fields, despite, or maybe because of, its ideological status. That is why I give particular importance to the operations of selection, omissions and exclusion that underpin the portrayal of the national landscape.

Two examples will serve to clarify my point. A crucial element of nationalist discourse is the establishing of national continuity -a precondition of representing the nation as subject of history. The vision of continuity is indispensable to any nationalist discourse. For our purposes the issue is not whether national continuity can be really affirmed. It cannot. The issue is the interpretation of this discursive construction as a series of successive integrations of historical periods and cultural features aiming at representing the nation as "it really was". Language is the second example. It is already well established that within the 19th century nationalist intellectual tradition language is considered an objective criterion of community. Such a conception is not 
without consequences. If language is taken as an objective criterion of national community then all its other historically important uses are eventually downplayed and with them all other "prenational" forms of community based on religion and locality also disappear.

However, it would be wrong to take nationalist discourse as a discursive practice that works only in continuities. Instead nationalist discourse should be analysed in terms of discontinuity as well, and at this point it is better to speak of discourses rather than discourse. Discourses do not simply build a commonly acceptable vision of national community. In the long run this vision is the product of competition among discourses each claiming truth status for its own account. In other words different discourses tend to accommodate different versions of national identity. This competition can be conceived as a dynamic field where separate discourses conceptualise identity criteria and perceptions of time and space and produce different versions of national community. Domination of one discourse requires its imposing its own classifications and perceptions over the others. But this is not necessarily a linear process, in the sense that it is usually discontinuous both with other and previous discourses. Yet, the final testing ground to arrange these discourses hierarchically is not only their rhetorical vigor, cohesion or power of representation but how powerful their reach is in the national political arena. Nationalist discourses do not limit themselves in establishing truth claims about the national community but they also take the form of mediators representing its political interests. Having established the legitimacy of the national community in consideration, nationalist discourses defended its cultural peculiarity by putting forward specific political claims and shaping political action in terms of national interests. At this level the interaction of discourses with politics is very tight, and politics becomes a matter of establishing who represents national interest. Yet, what qualified as "national interest" was far from unequivocal. What is important is to grasp how discourses shaped those interests at the same time that they appear to embody and represent them faithfully. Hegemony belonged to the discourse which not only made its own versions of national interests most appealing but shaped politics and action accordingly.

II. In this brief article I will attempt to elaborate some of these issues by addressing a specific question: that of the "non-Greek-speaking Greek" communities, speaking mostly Slavic, Vlach and Albanian but also Turkish and Arabic, and the way they were treated in Greek nationalist discourse. The question of "non-Greek-speaking Greeks" can be illuminated if one sets it against the context of the gradual construction of the dominant conception of Greek national identity. I will discuss this later on, but right now it is necessary to stress that this concept accommodated both language and religion. The Greek national community was conceived as a community that shared specific cultural features, especially the use of the Greek language and adherence to Orthodox Christianity. However this concept was not applied exclusively to the populations included in the Greek state at the moment of its foundation in 1830/1828. It was extended to include the Greek-speaking Orthodox communities still living within the boundaries of the Ottoman state. Therefore, many Ottoman Christian communities were thought of as part of the Greek nation as a consequence of their particular linguistic and religious features.

It was in the late 19th century that definitions of the Greek national community not based on language first appeared, to proliferate rapidly in the early 20th century. "[L]anguage...is not 
among the essential national characteristics," I. Kalostipis pointed out in 1886. "Language does not always indicate race/nation," claimed Ch. Cristovassilis in 1903. "Spoken language is not an adequate sign to define race [nation]," remarked Professor Kepetzis in a speech delivered in 1904. "[I] am not certain whether spoken language necessarily proves the nationality of a people," argued Ion Dragoumis. "Besides,... language is always of secondary importance for determining nationality," wrote A. Spiliotopoulos in his treatise on the "Vlachophone Greeks". In 1919, a veteran of the Macedonian struggle, K. Mazarakis-Aenian, repeated that "[l]anguage is not a feature of race or nationality, especially in the East.".

Such statements are remarkable not only because they were uttered by major figures of the Greek nationalist intelligentsia, but also because they present sharp departures from previous understandings. All in all, such statements underline a new direction of the Greek nationalist discourse which was based on a reconceptualisation of the linguistic criterion of nationality. This direction can only be understood in connection with emerging concepts of Greek national interests and political claims in Ottoman Macedonia and elsewhere. Strictly speaking the dislocation of language from its primary position in the structuring of national identity was a response to the "discovery" of non-Greek-speaking Christian communities and the need to accommodate them within the boundaries of the Greek national community.

Reference to "non-Greek-speaking Greeks" in Ottoman Macedonia and other Balkan provinces appeared frequently during the $1870 \mathrm{~s} .{ }^{6}$ This sudden interest can be explained. The establishment of the Bulgarian Exarchate in 1870 contesting as it did the ecclesiastical hierarchy of the Orthodox Patriarchate in Constantinople upset many Christian communities and proved to have long term effects. The major problem, however, was that ecclesiastical divisions did not follow linguistic lines of demarcation. Although the Exarchate appealed to Slavic-speaking communities, large numbers of Slavic-speaking Christians remained faithful to Constantinople.

"Non-Greek-speaking Greeks" acquired further political importance during the late 1870s as an effect of the Russian-Turkish war of 1877-78. Russia's attempts to create a large Bulgarian state was founded upon linguistic criteria and Slavic-speaking Christians were thought to be part of the Bulgarian nation. Given the existing national aspirations of other Balkan states in the area, the clauses of the San Stefano Treaty (1878) were met with widespread opposition, mostly in Greece and Serbia. In this complex combination of emerging rival national claims and perceptions of national belonging in Ottoman Macedonia, Greek diplomatic personnel prepared reports aiming at the classification of the Christian populations according to "nationality". However, in the face of the predominance of the linguistic criterion such classifications proved to be a demanding exercise as the bulk of the Christian populations were non-Greek-speaking. The use of the Greek language was limited to the urban centers and southern parts of Ottoman Macedonia, while in the countryside non-Greek dialects (Slavic, Vlach, Turkish and Albanian) were mostly used. In this juncture, non-Greek-speaking Christian communities, speaking mostly Slavic and Vlach, were officially incorporated in the Greek national community. ${ }^{7}$ As national rivalries in Macedonia increased, the category of "non-Greek-speaking Greeks" was extended to include other Christian communities, mainly Turkish and Albanian-speaking Christians. During the 1880s the Greek Ministry of Foreign Affairs received many similar reports prepared by diplomatic personnel in various Ottoman cities in Macedonia, Thrace and Epirus. ${ }^{8}$ 
Political expedience apart, the admission of non-Greek-speaking Christians within the Greek national community was due to the dominant ideological discourse where almost everything was interpreted in national terms. Greek diplomats, hard pressed to produce convincing evidence sustaining the Greek claims, took loyalty to the Orthodox Patriarchate as equivalent to loyalty to the Greek national cause. Such a position, however convenient, introduced a novelty as it was tacitly acknowledged that the specific groups thought as part of the Greek national community were deprived of the most distinctive feature of the nation: language. Given the prevalent conception of language in Greek national identity, such an acknowledgment presented a serious challenge to the dominant national discourse. The already established national criteria of identity had to be modified in order to accommodate political claims over populations who spoke no Greek at all, or in the best of cases used Greek as a second language.

The attempt was undertaken by specific groups of nationalist intellectuals whose leading figures were members of the staff of Athens University, journalists, schoolteachers and diplomatic personnel staffing some of the most critical posts in Macedonia. ${ }^{9}$ This involved three different, although interrelated stages. In the first place linguistic diversity within the Greek national community had to be accounted for. Second, alternative criteria of national identity had to be established. And third, nationalist discourse attempted to bolster up the Greek cause by underlining the "unique" cultural qualities of the Greeks, thus appropriating culture and civilisation exclusively for the Greek community. By the end of the 19th century this issue was directly addressed in books, pamphlets, and articles discussing questions of national politics with particular reference to the situation in Ottoman Macedonia.

Linguistic diversity within the Greek national community was not dealt with as an isolated phenomenon, but there were attempts to explain it within the dominant discourse of historical continuity. Eventually, nationalist discourse on Macedonia drew upon the historical narratives produced by K. Paparrigopoulos and others. ${ }^{10}$ The latter conceived history as a linear and nationally meaningful process where events piled one upon the other in a chronological sequence representing the movement of the Greek nation through time. As is well known, this historical schema

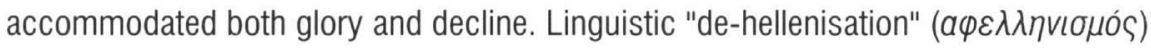
was posed and explained as an aspect of national decline. Greek historical narratives presented Macedonia and Macedonian history as an intrinsic component of Greek history even before the days of Philip II and Alexander the Great, when the political unification of the Greek nation was first realised. In this view, Macedonia remained Greek throughout antiquity and the early Byzantine period until the "barbaric" invasions of the seventh century A.D." As a consequence Macedonia saw a new wave of foreign domination coupled with Slavic settlement. Although the Byzantines emerged victorious and the Bulgarian kingdoms were suppressed, Bulgarian settlements remained in the land. According to these narratives it was during Ottoman occupation that a major change took place. It was at that time that Greeks began to abandon the use of the Greek language, adopting the language of their Bulgarian co-orthodox neighbors.

This issue was addressed in a memorandum sent by some of the leading figures of

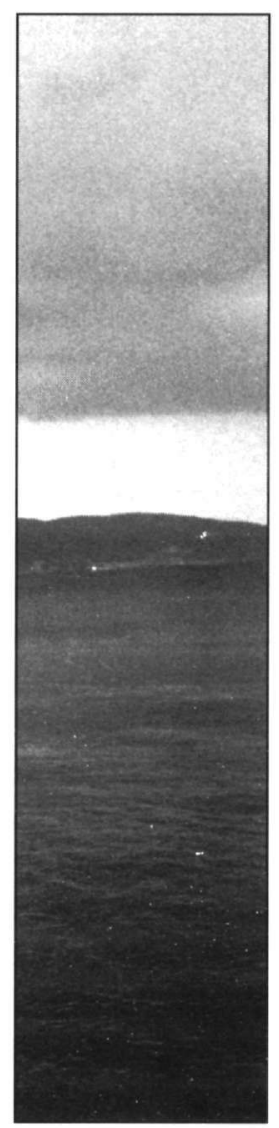


the Greek Orthodox community in Constantinople to the representatives of the European powers at the outset of the San Stefano Treaty in March $1878 .{ }^{12}$ In it they claim that although many Greeks had abandoned use of the Greek language, adopting a Slavic idiom as a means of communication with their Slavic neighbours, they had, nevertheless, fully retained their nationality and national character. Additionally, emphasis was laid upon the extinction of the post-Byzantine educational infrastructure, an effect of the Ottoman occupation which undermined the teaching of the Greek language. Other reasons were also cited. I. Kalostipis saw in medieval linguistic development not only ethnic but social divisions as well. Greeks being socially dominant as city-dwellers, landowners, clerics, and merchants, had to learn Slavic dialects in order to communicate with the Bulgarians. Bulgarians, on the other hand, being entirely tied to agriculture, "coarse and ignorant by nature" were not in a position to learn Greek. ${ }^{13}$ N. Kazazis repeats this argument. He claims that Greeks learned Slavic idioms only to communicate with the Slavs who being "sloth and mentally blunt by nature" were unable to learn the difficult Greek language, adding that this happened at a time when the Ottoman administration persecuted speakers of Greek throughout the Empire. ${ }^{14}$ According to Ch. Christovassilis, Greeks were forced to adopt the Slavic language, and in the long run to make it their own, because they thought it expedient for purposes of avoiding the child-levy (devsirme) imposed on them by the Ottoman administration. "When [the Greeks] realised that the Sultan spared Bulgarian children from this levy they adopted the Slavic idiom so as to show that they were not Greeks and thus to save their own children from the Turkish claws." ${ }^{15}$

Despite these developments, the argument goes, the Greek language did not disappear altogether, as it extensively affected non-Greek idioms. Thus, Greeks did not simply adopt foreign languages, at least not without affecting them in turn. In this context the Slavic spoken in Macedonia is not considered a pure Slavic idiom but rather a

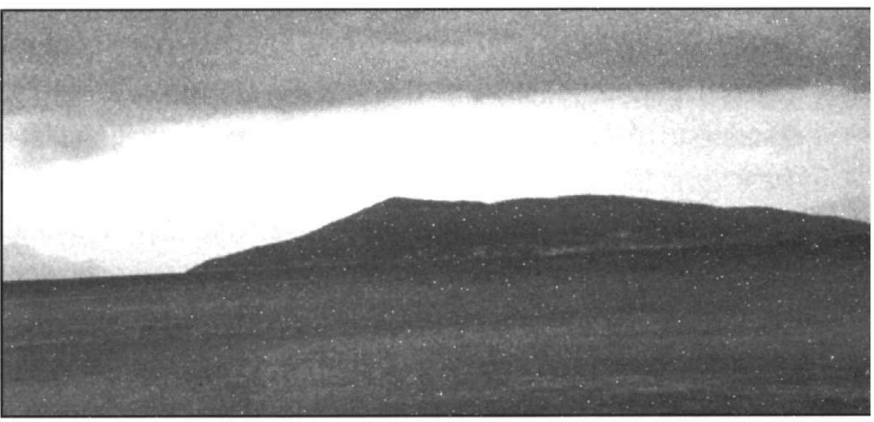
mixed Greek-Slavic dialect. The Greeks imposed parts of their lexicon onto the Slavs at the same time as they adopted the Slavic language. "In Macedonia and Thrace something remarkable happened. It was not only Greeks who, due to fear and social need, chose the use of another language, but many of the newcomers (Bulgarians) through intermarriage with the Greeks did adopt many Greek words and Slavicised them by adding Slavic endings. Thus this mixed SlavoGreek idiom not only is more eloquent than that used by northerners but it is also unintelligible

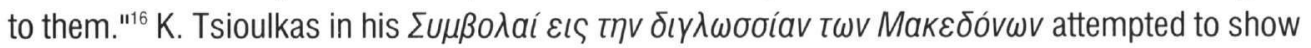
that the Slavic, or "Slavic in appearance" as he called it, idiom of Macedonia was in fact the ancient Greek Macedonian language. ${ }^{17}$ Ion Dragoumis with his well known rhetorical eloquence claimed that the Slavic idiom of Macedonia was not a Bulgarian language at all. ${ }^{18}$ Later on V. Colokotronis, in his attempt to prove the close racial affiliation of Greeks and Macedonian Slavs, placed strong emphasis on the Greek basis of the Slavic idiom in Macedonia. ${ }^{19}$ 
The Koutsovlach language is treated in the same way, as a Greek Latin idiom that was only intelligible within a similar context. "Les Valaques comme langue maternelle se servent d'habitude d'un idiome greco-latin, c'est à dire de mots issus du latin et du grec. En étudiant...cet idiome on remarque qu'il est mélangé de grec ancien et moderne avec ou sans terminations grecques." ${ }^{120} \mathrm{P}$. Kanellidis in his turn argued that the Vlach idiom had nothing in common with the Romanian language and that although grammatically influenced by the Latin its vocabulary was composed of Greek, Latin, and Albanian words. ${ }^{21}$ Thus, it was claimed, the Greek language, although it had disappeared in its pure form, held its ground partly by influencing linguistic development within non-Greek-speaking communities.

This approach is only an instance of a more general perception of the non-Greek-speaking Christians, the case of Macedonia being presented as simply an aspect of a more widely diffused phenomenon. Similar examples were further adduced to corroborate the validity of the argument about Macedonia. The example of the Turkish-speaking Christians thought to be part of the Greek national community is extensively used by Greek nationalist discourse. Kalostipis referred to the "Turkish-speaking Christians of Attalia who spoke no Greek but thought of themselves as Greeks" and compared them to the Greek-speaking Muslims who had emigrated from the Peloponnese in 1821 and "hated everything Greek."22 N. Kazazis refers also to the Turkish-speaking Greeks who had dropped the use of the Greek language due to extreme Turkish oppression: "I met with people who ignore the Greek language, the language of their ancestors... [there are] Turkish-speaking, Arabic-speaking, Armenian-speaking Greeks ... whose mother tongue is not Greek. They dropped the use [of the Greek language] during the time of oppression...."23 Addressing the question of the non-Greek-speaking Christians of Syria and Palestine, P. Karolidis, a professor of history at Athens University, put forward a similar analysis following the historical schema already applied to Macedonia. Discussing the case of "Arabic-speaking Greeks" in connection with the issue of the Orthodox Patriarchal See in Jerusalem, Karolidis attributed the abandoning of the use of Greek by the "Greeks in Syria and Palestine" and the adoption of Arabic to the Arab conquest of the area. ${ }^{24}$

All in all, the loss of Greek language was attributed to unfortunate historical circumstances at a time when the Greek nation was [politically] in decline. In fact, linguistic Slavisation was perceived as an aspect and a symptom of overall decline. However, or so the argument goes, historical circumstances and linguistic developments did not break the bonds of national community. In the absence of linguistic evidence other criteria of national identity were invented. Briefly the nationalist discourse insisted that linguistic "de-hellenisation" did not necessarily lead to the loss of national consciousness. For, although many Greeks adopted foreign languages, they never lost their ties with Hellenism, which conserved itself as an entity. Consciousness, therefore, emerged as the ordering principle of community, as an all-inclusive concept able to accommodate both Greek-speaking and non-Greek-speaking populations. ${ }^{25}$ Consciousness was perceived as a primordial quasi-metaphysical sentiment, shared by many, if not all, "non-Greekspeaking Greeks" and shaping not only individual but collective behaviour as well. Consciousness was the key category in the construction of the symbolic realm of national identity.

To be nationally meaningful consciousness had to express itself in a manifest way and this 
could be achieved only in connection to specific institutions, most importantly the Orthodox Church: Ioyalty to the Patriarchate of Constantinople was taken as an unmistakable indicator of national consciousness. But in this case it was loyalty to the Orthodox ecclesiastic hierarchy and not adherence to Orthodox doctrine that mattered.

The allegiance of non-Greek-speaking Christians to the Ecumenical Patriarchate of Constantinople as opposed to the Bulgarian Exarchate was interpreted as an indication of national sentiment and as a clear expression of national consciousness. In addition the [ecclesiastical] schism of 1872 was expressly interpreted in national terms and the ecclesiastical disputes that followed were set in the context of national rivalry. "The Schism has become Hellenism's most important weapon against Bulgarian aspirations. Due to the Schism the churches directly related to the Ecumenical Patriarchate of Constantinople, being thoroughly Greek in character, retained their [political] privileges," claimed P. Karolidis. ${ }^{26}$ Another writer insisted that "[t]he [Bulgarian] Schism proved to be the strongest barrier of Hellenism against Bulgarian propaganda," because "it enabled Slavic-speaking Orthodox Greeks in Macedonia to manifest their loyalty to their religious and national traditions represented by the Ecumenical patriarchate..."27

The nationalist discourse also underscored the "Greek character" of the Eastern Orthodox church -even of Orthodox Christianity in genera ${ }^{28}$-in various ways. It was argued that since Hellenism fused with Christianity in late antiquity, Eastern Orthodox Christianity, and the Orthodox church in particular, became the ark that saved the Greek nation during the hard times which followed the destruction of Byzantium. According to this discourse, the Greek nation was seeped in Orthodoxy to such an extent as to become inextricably bound to it. Although the establishing of this link did leave room for other national communities to claim similar bonds with Orthodoxy, the "Greekness" of the Orthodox church was not in question. The church was taken as another centre of the Greek nation, as the head of "Hellenism in captivity", and its "national" character remained unquestioned even in extremely critical writings castigating the policies pursued by the Patriarchate of Constantinople since the eruption of the ecclesiastical schism. ${ }^{29}$ It is no coincidence that this line of argumentation was extended to the case of nonGreek-speaking Orthodox Christians in Asia Minor, Syria and Palestine, where national and ecclesiastical antagonism did make their presence felt by the end of the 19th century, although not in the bitter form that is known in the case of Macedonia and Thrace. ${ }^{30}$ Again, loyalty to the Orthodox church and the institutions of the Orthodox communities were treated as an unmistakable sign of Greek national consciousness.

In addition to the criterion of ecclesiastic loyalty, nationalist discourse privileged another field of experience: enrollment in schools founded and run by Greek communities in Macedonia and elsewhere was granted a similar significance. "National life ... brought itself to a peak in education. Macedonia shows an active zeal towards the civilising endeavour to expand the Greek language, education and faith," stated I. Kalostipis as early as $1886 .^{31}$ It is well known that the establishment of school networks in the Ottoman empire was a major initiative since the early 1870 s. Although this network was not primarily designed to uphold national politics, it was eventually entangled in the national rivalry in Macedonia and elsewhere. Schools in Macedonia were financed by private associations and, increasingly, by the Greek state itself. Being a 
novelty, especially in the agricultural areas of the Ottoman empire, schools were usually performing poorly. During the late 19th century, schools established by Greek, Bulgarian, Serbian and Romanian initiatives proliferated rapidly. As such, schools appealed to a broad audience and functioned not simply as educational units but as national symbols as well. It was on this level that a sharp national competition took place. Numbers of schools and school attendance were perceived as evidence of choices guided by national consciousness. This symbolic competition favored mostly the Greeks since their social and economic resources were far more powerful than those of their rivals. The Greek nationalist discourse heavily emphasised numbers of schools and school attendance. After all it was through schools that "non-Greek-speaking Greeks" would be enabled to regain their mother tongue. In addition, as school enrollment was quantifiable, it could provide a vivid illustration of national inclination in the form of (presumably self-evident) school statistics. Occasionally, it was even claimed that the Greek student population reflected the demographic preponderance of the Greek community over their rivals. ${ }^{32}$ No wonder that such statistics together with information on educational matters figured heavily in most pamphlets, books and articles supporting the Greek cause in Macedonia. ${ }^{33}$ Predominance in education was symbolically extended to mean, at least to a national audience, overall national predominance in the area. ${ }^{34}$

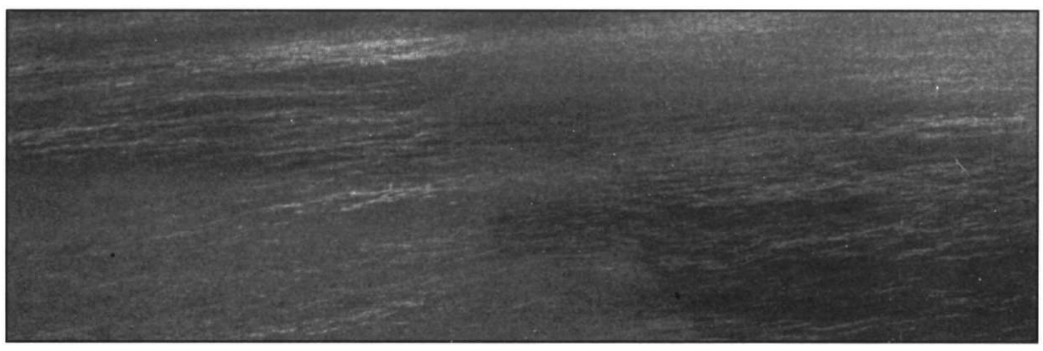

By insisting on ecclesiastic allegiance and school choice, nationalist discourse shifted the argument from the slippery surface of spoken language to a more stable ground. Alternative criteria of identity established alternative versions of community even at the expense of the dominant, language-oriented versions of national identity. Nationalist discourse did not limit itself to establishing convincing national criteria. It also attempted to procure a vision of the imaginary link of the Greek community with [Western] civilisation. Certainly this vision was not simply a response to the question of "non-Greek-speaking Greeks" but it was part of the more general discourse on national claims in Macedonia and elsewhere. In addition, this vision did not emerge in connection with the Macedonian question. Similar statements can be traced back to the 1840s, to mention only the well known speech of I. Kolletis in the Greek National Assembly in 1843-44, ${ }^{35}$ and even further back to the period of Greek Enlightenment. What is novel here is that Greek communities were represented as bearers of civilisation par excellence in a way that excluded any other community from claiming a similar link. In this case we are interested in the production of discursive stereotypes that associated particular communities with specific qualities ${ }^{36}$ The Greek national community was invested with superior cultural traits which set it apart mainly, but not exclusively, from the Bulgarians. In this discursive configuration, particular fields of social experience were granted a privileged position. Social and cultural superiority were, supposedly, expressed in economic and educational predominance. Yet, this superiority was not simply projected against a comparative Balkan background. It allegedly derived from the intrinsic links of Greek culture with European culture. Appropriation of 
[Western] culture and civilisation was an integral component of the Greek nationalist discourse in its attempt to connect the Greek cause, especially in Macedonia, with European values. This line of argumentation aimed at two different directions. The first direction was towards the Greek-speaking public. The Greek cause in Macedonia allowed the reaffirmation of the "privileged" position of the Greek nation vis-à-vis civilisation proper. The second was towards a broad European audience which supposedly favored Bulgarians and failed to recognise Greek rights in Macedonia and elsewhere. ${ }^{37}$ Legitimising national claims was set against a background of European politics and power games.

III. The category of "non-Greek-speaking Greeks" was discursively constructed both in terms of discontinuity and continuity with previous discourses and in connection to an "existing reality" it purported to express. First, the discourse on "non-Greek-speaking Greeks" can be interpreted in terms of discontinuity. Attention to "non-Greek-speaking Greeks" leads to a reconceptualisation of language as a criterion of national belonging. The dominant conception of the Greek national identity, although not restricted to language alone, strongly emphasised the linguistic homogeneity of the Greek national community. The linguistic criterion could not be smoothly applied to Christians in Ottoman Macedonia and elsewhere. Linguistic criteria were even less convincing in a multilingual environment where language did not work as a dominant feature of identity among the people involved. Yet, the nationalist discourse had to accommodate claims on both Greek and non-Greek speaking populations. Eventually language as a criterion of identity had to be played down, even ignored, and other criteria were pushed to the fore. This was not without consequences on the structuring of Greek national identity. As language lost its privileged position, other criteria, such as those mentioned above, were invented to maintain the coherence of this structure. Accordingly, nationalist discourse concocted a different version of national community whereby the meaning of language as a criterion of national community was reconceptualised and other elements of identity were privileged in its stead. This new conception classified Christians according to new criteria of identity, allowing for the redefinition of the boundaries of national community in the contested areas of the Ottoman empire. However, the dislocation of the language criterion from its erstwhile position in the case of the "non-Greek-speaking Greeks" was not taken to its logical conclusion, i.e. the complete exclusion of linguistic criteria of national identity.

The elaboration of this discontinuity reveals the way these novel orientations interacted with the original conceptual framework they departed from. Nationalist discourse is a system of representation of reality and both its mechanisms and demonstrative strategies are directly related to the categories of perception that go back to the conditions of its production. In this case what matters most is the manner in which the category of the "non-Greek-speaking Greeks" is brought to our attention: as a community(ies) using a particular language. In other words these communities were identified and approached on the basis of their linguistic profile. No community was thinkable without consideration of its linguistic status. This was the case because language as a criterion of nationality was so thoroughly inscribed into perceptions of the Greek national identity that it was thought to be an intrinsic part of it. Until the discovery of "non-Greek-speaking Greeks", language was among the yardsticks of national community. In 
this context the linguistic status of these communities was impossible to be ignored; it was indeed the first feature to attract attention. Accordingly, the perception of the "non-Greekspeaking Greeks" worked in two ways. It lead to a reconceptualisation of language as criterion of national identity and extended the imaginary boundaries of the Greek national community, without, however, destroying the linguistic criterion of national community.

This contradiction is evident in two ways. First, the new conceptualisation of language, and its consequences, did not lead to a new theory of the connection between language and nation. ${ }^{38}$ As already mentioned, the emergence of the "non-Greek-speaking Greek communities" was treated as an historical accident. Second, language was extensively used as evidence of Greek nationality in many other cases.

It should be noted in this respect that the elaboration of the category of the "non- Greek-speaking Greeks" drew upon the conceptual framework developed in the context of the "Language Question" in Greece. During the 1880s the language controversy was rekindled after a long interval along a well trodden pattern: emphasis on the use of demotic language versus the use of an invented learned language (katharevousa). This is not the place to expand on this issue and a brief comment will do. Language disputes first erupted in the late 18th and early 19th centuries among Greek speaking intellectuals influenced by theories of the European Enlightenment. One of the major products of the Greek Enlightenment was the reappraisal of ancient Greece as one of the main points of reference, as the ideal past and the symbolic field of comparison. ${ }^{39}$ Within the intellectual tradition of the Greek Enlightenment special attention was accorded language as the main criterion of community and specific questions were asked as to the linguistic state of the "Greek nation" in comparison to its ideal past. The loss of linguistic standards was only too obvious to ignore, and the linguistic developments leading to the shaping of demotic Greek were directly ascribed to the political decline of the Greek nation and to the foreign occupation that caused it. Intellectuals like A. Korais and $P$. Kodrikas, although in strong disagreement on most other linguistic issues, were in accord on this aspect. The loss of linguistic standards of ancient Greek was considered tantamount to the barbarisation ( $\varepsilon \kappa \beta a \rho \beta \alpha \dot{\rho} \rho \omega \sigma \iota \varsigma)$ of the Greek language itself. $^{40}$

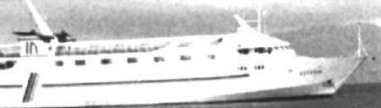

This argument was again employed during the new phase of linguistic conflicts. Supporters of katharevousa perceived demotic Greek as a compound of dialects the use of which was blocking the establishment of a learned Greek language. Again demotic Greek was directly linked to the period of decline and represented as a product of "slavery". ${ }^{41}$ The portrayal of the "nonGreek-speaking Greeks" on a similar historical canvas placed them on an equal footing with other Greek communities which having retained some form of Greek had, nevertheless, 
abandoned formal and learned linguistic standards altogether. In this way the discourse on "nonGreek-speaking Greeks" re-enacted the historical drama already rehearsed in Greek nationalist discourse and made the inclusion of these communities into the Greek national community possible. Political decline, with all its rhetorical synecdoches, is used as a model of interpretation. Departure from the ideal past is not without consequences. As the Greek nation declined, some of its fundamental characteristics were attenuated. In the linguistic field this regression was reduced to the perversion of the forms of the ideal language. If demotic Greek was a linguistic product of slavery and foreign occupation then other linguistic forms could also be accommodated within this discourse, the case of "non-Greek-speaking Greeks" being one of them.

Furthermore, the discourse on "non-Greek-speaking Greeks" also reinforced the religious component of the national identity. Orthodoxy was certainly already well entrenched in Greek nationalist discourse. The religious dimension was already effective during the Greek war of independence, especially among the people, and maintained its influence well after the establishment of the Greek state. It is also known that the influence of Orthodox tradition strengthened its hold on both the literate and illiterate during the $1850 \mathrm{~s}$. ${ }^{42}$ However, it is not Orthodoxy that interests me here but the Orthodox hierarchy whose position vis-à-vis the Greek nation had been represented in various conflicting ways. Although Orthodoxy was hardly ever questioned as a defining feature of the Greek nation, the Orthodox hierarchy was frequently treated with suspicion, even outright rejection from the time of the Greek Enlightenment up to the 1870s. ${ }^{43}$ The discourse on the "non-Greek-speaking Greeks" reveals the way allegiance to the Orthodox hierarchy was established as an indication of Greek national conscience. It was only in connection to the Macedonian question and other similar issues that the Orthodox hierarchy came to be included into the symbolic realm of the Greek nationalist discourse in an unquestionable way. It was only then that the Greek character of the church and of the Orthodox hierarchy was repeatedly affirmed, despite frequent charges against Orthodox clerics who supposedly pursued anti-national policies. This line of argumentation was not limited to the Christians communities of the Ottoman provinces in the Balkans but was extended to the Orthodox communities in Asia Minor and Syria. ${ }^{44}$ By introducing loyalty to the Patriarchate as a criterion of national consciousness, nationalist discourse effected a nationalisation of the church itself, representing this "ecumenical" institution as a part of the Greek cause, a point of view which, incidentally, was readily accepted by rival nationalist discourses. ${ }^{45}$

It should be noted that by strengthening the religious field in the way just described, the discourse on the "non-Greek-speaking Greeks" also reinforced the vision of modern Greece as heir to Byzantium. Again, Byzantium and Byzantine civilisation had already been integrated into the history of the Greek nation since the 1850s. By the time the edition of Paparrigopoulos' monumental work was concluded, the last traces of the Enlightenment tradition which despised Byzantine culture, treating it as synonymous to bigotry, had been erased. ${ }^{46} \mathrm{It}$ is well established that the forging of the Byzantine link in the 1850s completed the chain of historical continuity and reinforced the influence of Orthodox and Byzantine tradition. My point is that the discovery of the "non-Greek-speaking Greeks" imaginatively linked the Byzantine tradition to living human beings and extended it beyond the borders of the small state to include Christians who did not speak Greek but who, it was argued, were nonetheless Greeks due to their religious allegiance, 
which could be traced back to Byzantine times. In this manner the representation of the "nonGreek-speaking Greek" communities coincided with the vision of the "Great Idea" which, based as it was on the imperial tradition of Byzantium, was incompatible with the territorial dimension of ancient Greece. As P. Karolidis put it: "Some not only insulted both ancient and modern Greece by sustaining that there is no relation between Hellenism and the Byzantine world, they went as far as suggesting that Byzantium is inimical to Greek culture.[...] [F]or them the rise of Greek culture was limited in the areas south of [Mount] Olympos and reappeared [only] in the new francolevantine Greek state. ${ }^{147}$

This brings us to our last point. Discourse on "non-Greek-speaking Greeks" can be directly linked to national policies as it reinforced the ideological hegemony of the "Great Idea" form of nationalism in Greek politics. Being part of a broader discourse it attempted to reshape the boundaries of the Greek "community" by establishing truth claims on particular Christian communities in the Ottoman Empire. In that, it was not only working in relation to the shaping of Greek national interests in the face of rival national claims. It was not even the aspect of legitimacy of national claims, which were tightly linked to such truth claims, that mattered most. This discourse was mainly working towards imposing a form of national politics able to meet the "expectations" of communities already conceptually integrated into the Greek nation. Seen against the background of the bitter disappointment haunting Greek politics after the GreekTurkish war in 1897 this discourse remembered the "unfinished tasks" and nurtured a sense of national duty which, I think, strongly influenced the policies of the Greek state in Macedonia and elsewhere.

\footnotetext{
${ }^{1}$ I am referring to the following general works on nation and nationalism. E Gellner, Nations and Nationalism [Greek edition, Athens 1992]; B. Anderson, Imagined Communities; Rerflections on the Origin and Spread of Nationalism. London, 1983; J. Breuilly, Nationalism and the State. Manchester, 1992 2 ; E. Hobsbawm, Nations and Nationalism since 1780. Cambridge, 1990. The modernist suggestions have challenged and were challenged by the "ethnic" approach to the national question. See A. D. Smith, The Ethnic Origins of Nations. Oxford, 1986 and National Identity. London, 1991. See also J. Hutchinson, Modern Nationalism. London, 1994.

${ }^{2}$ In his introduction to Nations and Nationalism, Eric Hobsbawm envisaged the possibility of an alien historian landing on earth after a nuclear destruction and his inevitable stumbling upon the concept of nation in his attempt to grasp the course of human history in its final stage. To make things easier for his extraterrestrial colleague, Hobsbawm suggested a short reading list of books regarding the national phenomenon. Yet, this list "would contain very little that was written in the classic period of 19 th century liberalism because [....] very little other than nationalist and racist rhetoric was being written there."
}

${ }^{3}$ Rhetorical mechanisms are nothing but figures of thought. Their possible separation creates a false dualism, as points out Stephen Bann who, quoting Dan Sperber, uses the notion of "cognitive rhetoric". See S. Bann "History as Competence and Performance" in F. Ankersmit, H Kellner (eds.), A New Philosophy of History. London, 1995, p. 199.

${ }^{4}$ This discussion draws mainly upon M. Foucault's approach of discourse as a system of statements that both enable and constrain thinking. See M. Foucault, "The Order of Discourse" in R. Young (ed.), Untying the Text; a 
Poststructuralist Reader. London and New York, 1987. See also Foucault's treatment of discourse in The Archaeology of Knowledge. London, 1989. This approach should be seen in relation to discussions regarding new conceptualisations of language and discourse in historical studies. See cfl, G. Stedman Jones, Languages of Class. London, 1983; D. La Capra, "Rethinking Intellectual History and Reading Texts" in D. La Capra (ed.), Modern European Intellectual History, Reappraisals and New Perspectives. London, 1983; J. E. Toews, "Intellectual History After the Linguistic Turn" in American Historical Review, 1987; K. M. Baker, "On the Ideological Origins of the French Revolution" in K.M. Baker, Inventing the French Revolution. Cambridge, 1990; P. Bourdieu, "The Production and Reproduction of Legitimate Language" in P. Bourdieu, Language and Symbolic Power. Cambridge, 1993; R. Chartier, "Intellectual History / History of Mentalities", in R Chartier, Cultural History. Cambridge,1993 and "History between Narrative and Knowledge" in R. Chartier, On the Edge of the Cliff: History, Language and Practices. Baltimore and London, 1997.

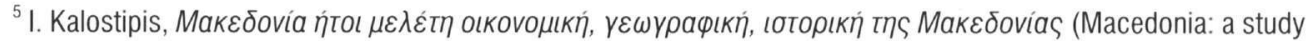

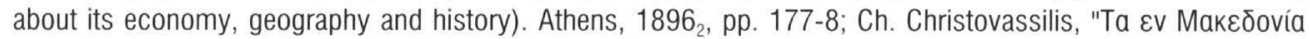

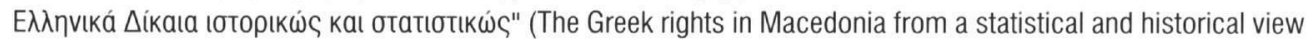

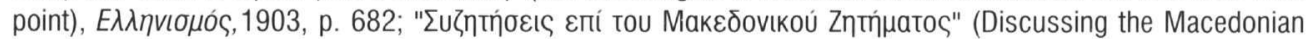

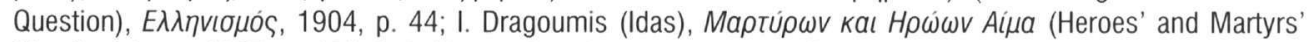
Blood). Athens, 1907, p. 101; I. Spiliotopoulos, Les vlachophones Grecs et la propagande roumaine. Athens,

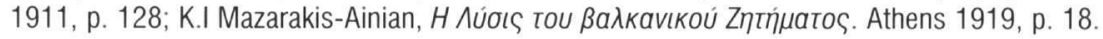

${ }^{6}$ Educational reports prepared by the Greek Literary Society in Constantinople for the purpose of financing schools in Ottoman Macedonia provide ample evidence on non-Greek-speaking Christian communities. See

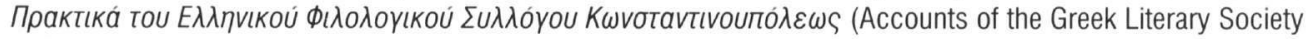
in Constantinople), 5(1870-71), pp. 106-110; 7(1872-3), pp. 205-219; 8(1874), pp. 252-268; 9(1875-76), pp. 182-198; 10(1876), pp.180-200; 11(1878-79), pp. 192-200; 13(1880), pp. 56-84. The national and linguistic status of the Turkish-speaking Christian communities of Kappadokia incited the first formal debate regarding "non-Greek-speaking Greeks". A. D. Mordman's argument that Turkish-speaking Christians in Cappadokia were not Greeks and had never used the Greek language (see his Die Trogloditen von Kappadokien, 1861) raised many eyebrows in Greek intellectual circles in Constantinople. An interesting dispute followed the presentation of this book in the Greek Literary Society of Constantinople regarding concepts of language, history and community.

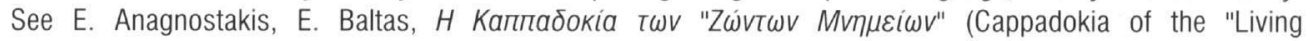
Monuments"). Athens, 1990, pp. 24-28.

${ }^{7}$ See for example the 1884 report of the Greek consul in Monastir P. Logothetis in K. Vakalopoulos, To

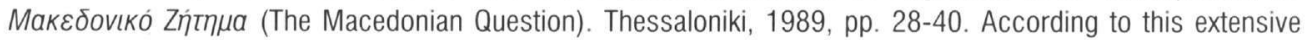
report the Greek population in the area included large numbers of Slavic, Vlach [Koutsovlach] and Albanianspeaking Christians.

${ }^{8}$ It is noteworthy that Greek consular reports in the early 1870 s referred to these Christians as Bulgarian-Greeks as opposed to Bulgarian-Slavs, obviously in an attempt to describe the right combination of language and national orientation. Later on the sequence of words changed and those non-Greek-speaking Christians thought to stand for the Greek cause were frequently mentioned as Greek-Bulgarians. Alongside mentioning "non-Greekspeaking Greeks" Greek diplomatic reports frequently refer to communities with "fluid" national consciousness. This akward term, applied to Orthodox Christians showing no national affiliation whatsoever, was invented in the attempt to grasp a non-national reality, an order of things quite unthinkable within a nationally oriented understanding of things.

${ }^{9}$ This article draws exclusively upon published material. The reason I value this material is because it was publicly oriented. Pamphlets, books and journals were intended to reach as wide a public as possible. They were extensivelly read and the popular imaginary was mostly constructed in relation to this kind of material. In addition I sense that published, or secondary as it is pejoratively called, material has been usually, and unjustly, treated as a source with less value due to its polemical and "subjective" dimension. In comparison, diplomatic reports and correspondence were thought to be more "objective", in closer relation to historical reality than "secondary" sources. To the best of my knowledge diplomatic sources are simply another kind of material as textually bound and as discursively produced as any. They lack, in addition, any power of the popular imaginary, other than the mystifying appeal to historians as sources whose examination could unearth the "truth" and allow the writing of the "real" history.

${ }^{10}$ The historical continuity of the $c$. 'ek nation and the positioning of Byzantium as part of this continuity was first 


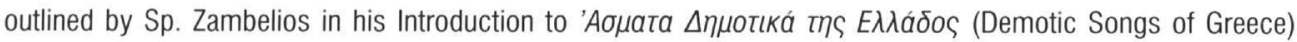
Corfu 1852. Yet it was K. Paparrigopoulos who took the main credit as his eight volume History of the Greek Nation, completed between 1860 and 1875, transformed historical knowledge completely and enabled the discursive domination of this historical representation in academic and learned circles. See K.Th Dimaras, $K$.

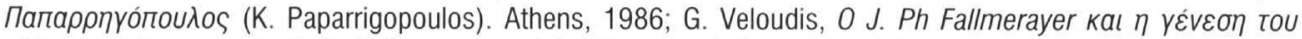

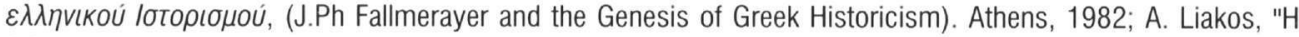

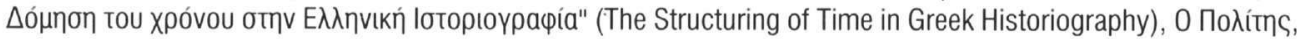
Dec 1993.

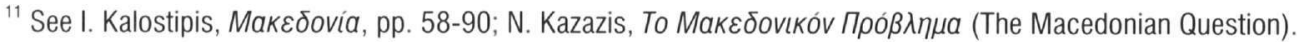

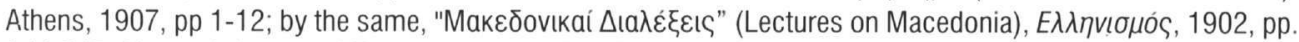

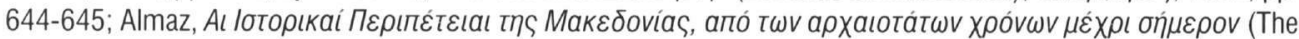
Historical Adventures of Macedonia from Antiquity to the Present). Athens, 1911, pp. 10-23; V. Colocotronis, La Macedoine et l'Hellenisme, étude historique et ethnologique. Paris, 1919, pp. 50-107. On the linguistic debates

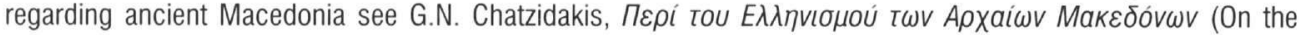

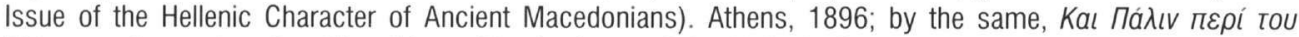

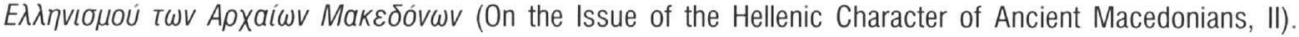
Athens, 1911.

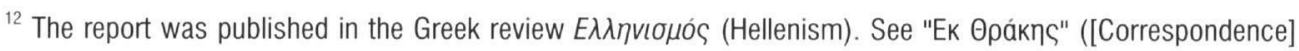

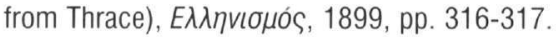

${ }^{13}$ I. Kalostipis, Makeסovia, pp. 139-144.

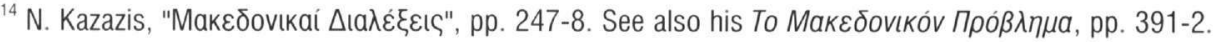

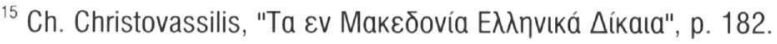

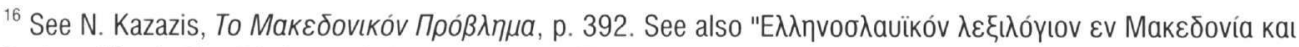

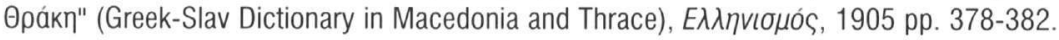

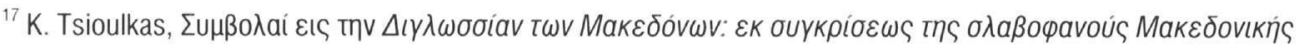

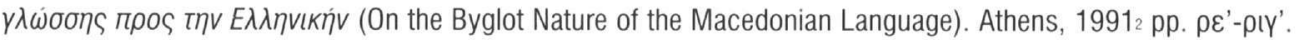

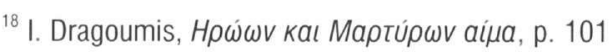

${ }^{19} \mathrm{~V}$. Colocotronis, La Macedoine et l'Hellenisme, pp. 502-3, 507-513.

${ }^{20}$ A. Spiliotopoulos, Les Vlachophones Grecs et la propagande Roumaine, pp. 20-21.

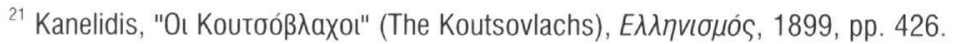

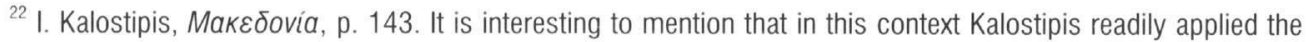
dominant (in Ottoman society) perception of community based on religion: "In order to classify [people in the ] East according to nationality, religious consciousness is much more valid than language... There are Greek speaking [people] who have no Greek national concsiousness and there are Turkish speaking [people] who do not belong to the Turkish nation. Religious belief sets the former with the ottoman [i.e muslim] family and the latter with the Greek family", op. cit 105.

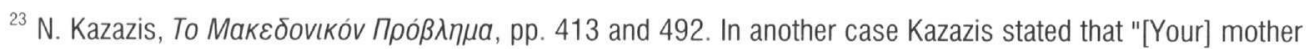
tongue was lost during the sinking of our nation... But [your] national consciousness did not disappear from your hearts. And when this consciousness reemerged you set yourselves again to the learning of your mother tongue".

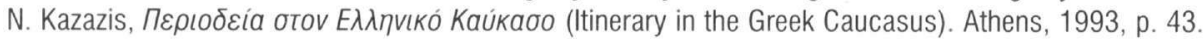

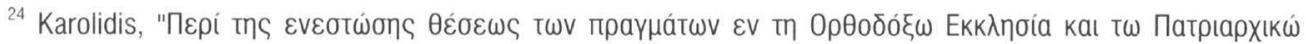

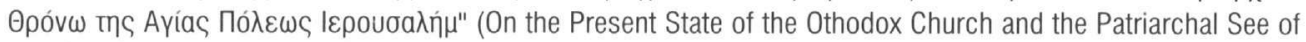

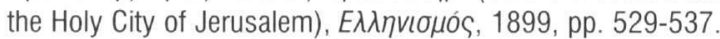

25 "[N]ational consciousness in Macedonia is entirely Greek.... National consciousness cannot be taught, cannot be forced upon, cannot be marketed. It is an inherent, mysterious and in many ways difficult to explain sense"

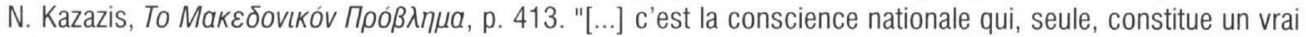
criterium de nationalite. C'est la, par contre, le criterium que choisissent toujours les Grecs, qui n'ont jamais manifeste le moindre interet pour les populations Slavophones privées de conscience nationale grecque". V Colocotronis, La Macedoine et l'Hellenisme, p. 516. These are two of the many references on national 
consciousness as a primordial, almost metaphysical, state of mind.

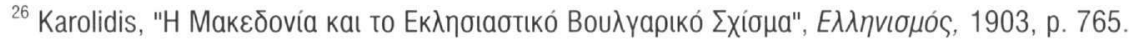

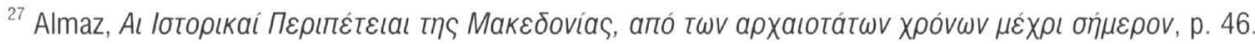

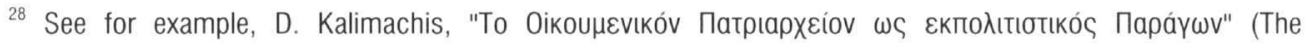

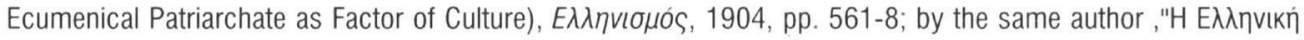

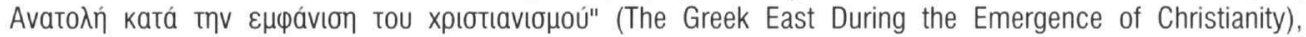

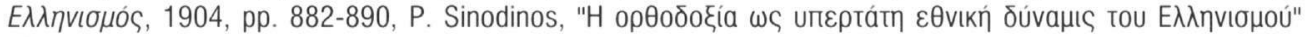

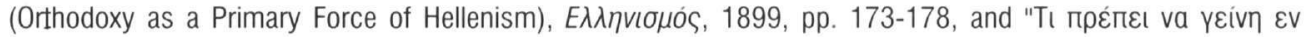

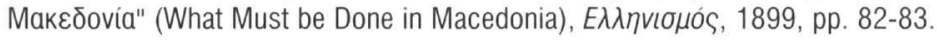

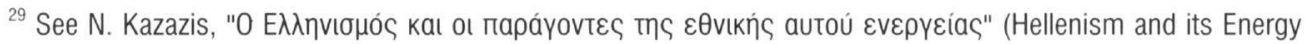

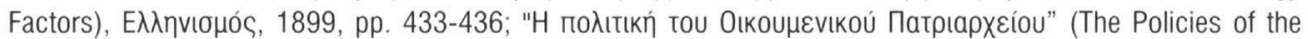

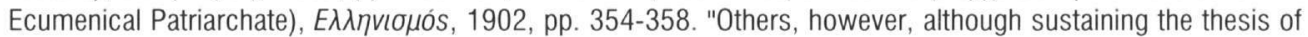
the Greek character of the church, refused to associate directly its political priorities with those of the Greek state.

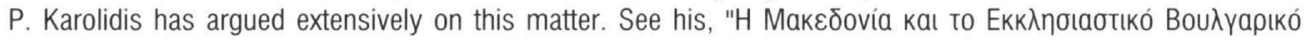

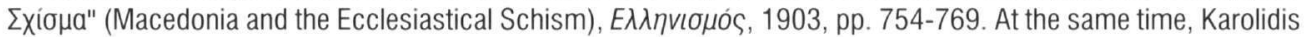
saw in some segments of the church the most ardent guardians of Hellenism. See the way he treats the Orthodox

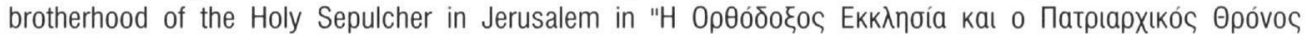

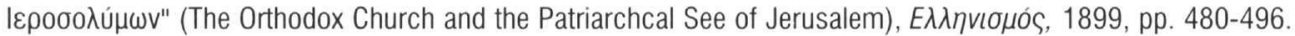

${ }^{30}$ In these areas the Orthodox communities were the target of Western missionaries and of the Russian "panOrthodox Society" which attempted to strengthen Russian influence in Syria and Palestine mostly at the expense of the Eastern churches. See Th. Stavrou, Russian Interests in Palestine, 1882-1914. Thessaloniki, 1963 and D. Hopwood, The Russian Presence in Syria and Palestine 1843-1914: Church and Politics in the Near East. Oxford, 1969. Russian involvement was treated with suspicion and interpreted, especially in Athens, as simply part of an overall Pan-Slavist attempt to dominate the East by imposing clerics of "Arab" extraction on the Partiarchal Sees of Antioch and Jerusalem. At the level of the communities involved, however, attitudes towards these events differed extensively and in no way can be simply understood in national terms. See my "H סiáxuon

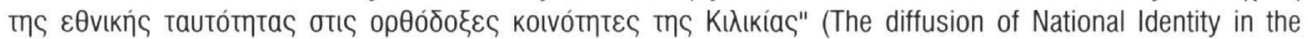

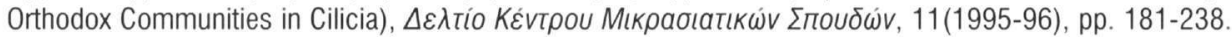

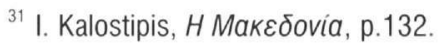

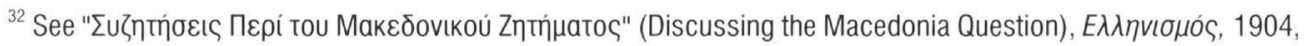
p. 45. This argument was extensively used against Romanian claims on the Latin- speaking Koutsovlach communities. It appears that the Romanian state spent large amounts of money for establishing Romanian schools in Macedonia but with no apparent success. Most Koutsovlach communities eventually thought themselves of as part of the Greek national community.

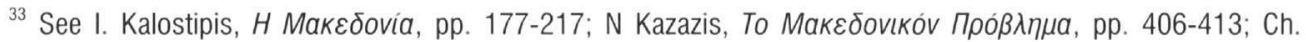

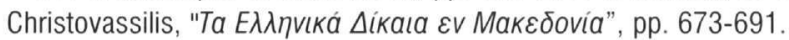

34 "The numbers alone (of schools, pupils and teachers) are sufficient to prove even to the most mistrustful

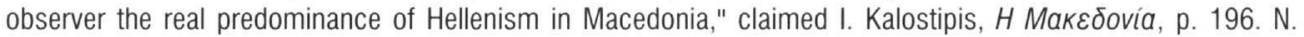
Kazazis, after reviewing existing information about schools in Macedonia, claimed that "The Greek education [in

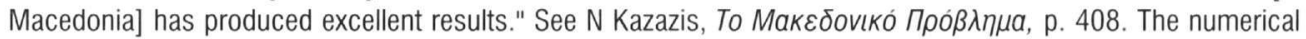

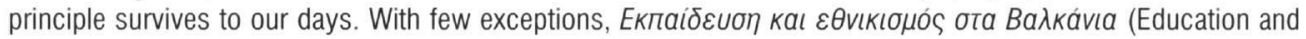
Nationalism). Athens, 1993, by S. Vouri is one of them, Greek literature on education in Macedonia sees in education an evidence of Greek claims.

${ }^{35} \mathrm{I}$. Kolletis, one of the leading political figures of the revolutionary and post-revolutionary periods argued in favor of admitting "eterochnones" Greeks, i.e. Greek-speaking Orthodox Christians born outside the borders of the new state, into the Greek state administration. In this connection Kolletis presented the view of the Greek national community that accomodated both language and religion. He also put emphasis on the civilizing mission of Greece as the bearer of [Western] culture in the East. In his view the future of the Greek nation was associated with the spreading of culture and civilisation in the East, a mission which Kolletis called the "Great Idea". See his

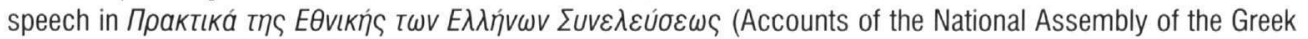
nation). Athens, 19932, pp. 190. 
${ }^{36}$ "Bulgarian history is a history of brutality, of barbarian incursions, of ravaging... [in contrast] Greek history stands for culture and the defense of the highest values of civilisation......] There is no [cultural] product of

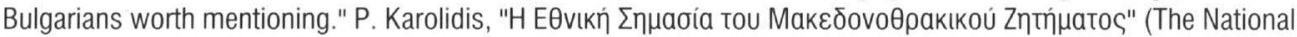

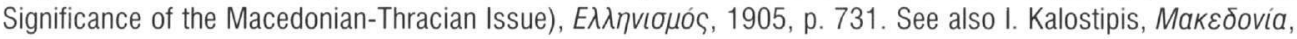

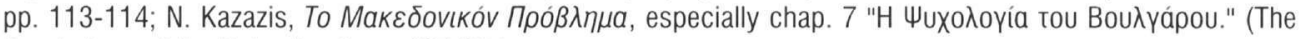
Psychology of the Bulgarians) pp. 187-204.

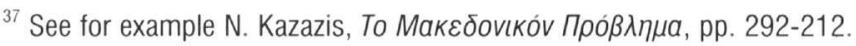

${ }^{38}$ The only exception is $\mathrm{P}$. Karolidis, who ventured to theorise on the relation of language and nation in a different way. His analysis rests upon the division of literary and demotic forms of language which he invests with different meaning. Karolidis elaborated his theory in connection to the non-Greek-speaking Christians of Syria and Palestine but extended it to the Balkan provinces of the empire, although in a less theoretical way. In his "H EӨvikn

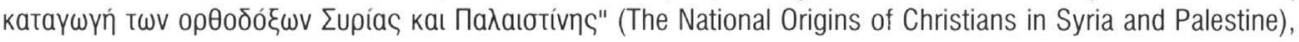
Karolidis discriminates between language as natural tongue used in everyday life and language as the medium of expression of mental and intellectual life and claims that only in the second case was it possible to accept language as a national feature. Op. cit. pp. 34-43. See also his treatment of Kutsovlach language and

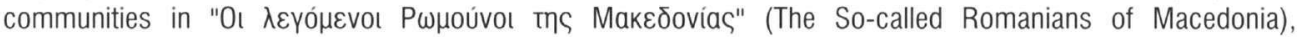

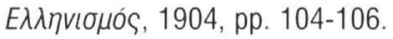

${ }^{39}$ The imaginary link between ancient and modern Greece has been extensively discussed. See the pioneering

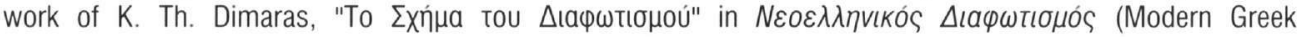
Enlightenment). Athens, 19895, pp. 22-119, and his "Greece 1750-1830" in K.J. Dover (ed.), Perceptions of

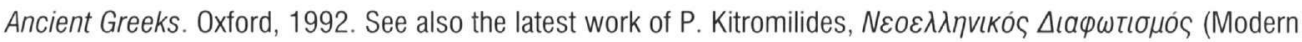
Greek Enlightenment). Athens, 1996, pp. 83-124.

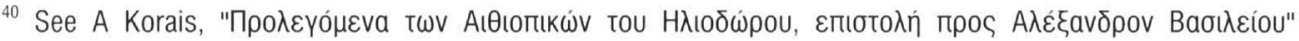

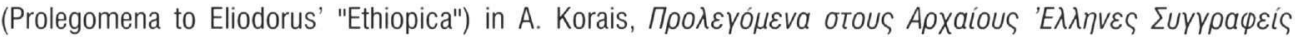

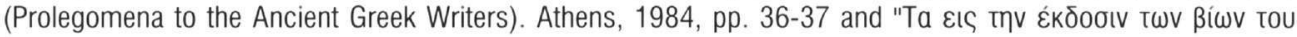

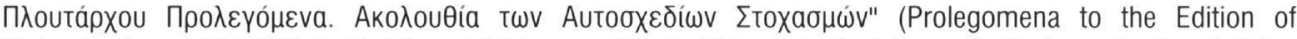

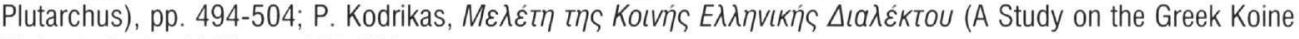
Dialect). Paris, 1818, pp. 225-226.

${ }^{41}$ See for example the way G. Mistriotis, a professor of Greek letters at the University of Athens and one of the leading supporters of katharevousa, treated demotic Greek in his dispute with $\mathrm{G}$. Hatzidakis about a project of

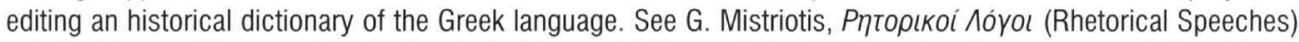
vol. 3, Athens, 1908, pp. 169-177; vol. 4, Athens, 1910, pp. 201-206. See also the argument of Karolidis "H

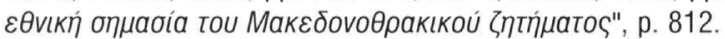

${ }^{42} \mathrm{~K}$. Th. Dimaras pinpointed the density of practices and statements strengthening the position of the Orthodox

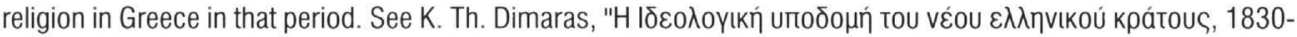

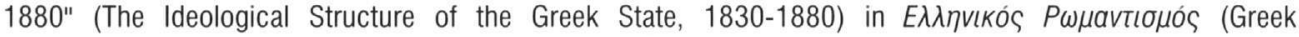

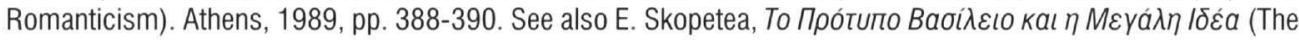

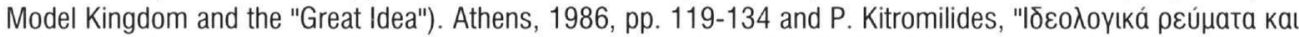

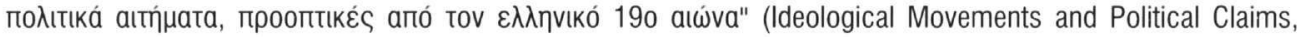

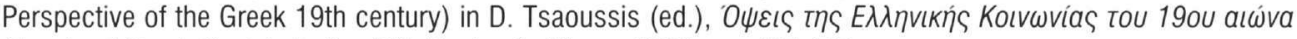
(Facets of Greek Society in the 19th Century). Athens 1984, pp. 107-121.

${ }^{43}$ Reaction towards the Patriarchate of Constantinople and the Orthodox hierarchy was based in Enlightenment literature. A. Korais, whose relations with the Orthodox church were, to say the least, unstable, is responsible for

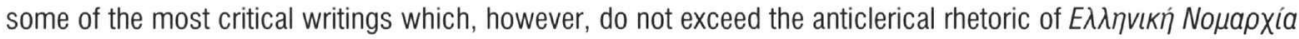
(1806) probably the most representative work of that period. Relations between liberal-minded intellectuals and the church remained bitter untill the establishment of the Greek state. The establishment of the autocephalous church of Greece in 1833, in complete disregard of Eastern church rules, further affected an already burdened relation. Although relations between the Greek state and its church with the Orthodox patriarchate were officially restored in 1850, opposition to the patriarchate emerged again, this time among lay Orthodox communities in the Ottoman empire in connection to the reform of the Orthodox community (millet) in the Ottoman empire in 1858-1862.

${ }^{44}$ By privileging literary language as a national feature P. Karolidis included both Turkish and Arabic-speaking Christians within the Greek national community. As he puts it literary Greek was the language of the church and 
of Orthodox ecclesiastic ritual. Therefore, non-Greek-speaking Orthodox Christians expressed their national orientation by following the "Greek", i.e. Eastern Orthodox, ritual alone, which according to Karolidis was the

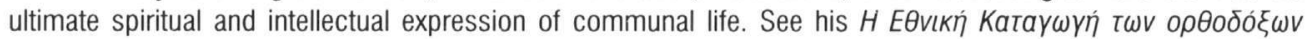

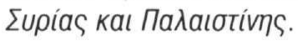

${ }^{45}$ The relation of the Orthodox Church and the Patriarchate with nationalism and national claims demands a brief comment. The Orthodox patriarchate remained the "guardian of Orthodox Oecumene" until the end of the Ottoman empire. This role, which it attempts to restore today, guided the policies of the church during the 19th century, a period which saw the gradual but consistent diminution of its influence. It must be remembered that the church was defending an Orthodox community in the face of intruding national movements. This defense was founded upon a particular symbolic system and on different and rival national representations. See P. Kitromilides "Imagined Communities and the Origin of the National Question in the Balkans" in M Blinkhorn, Th Veremis (eds.), Modern Greece: Nationalism and Nationality. Athens, 1990, pp. 23-66; H. Exertzoglou, "To "Проvoulakó" Zńmua'” (The Question of Ecclesiastical Privileges), Ta lotopıká, 16(1992). It must also be remembered that the church treated the Greek language, allegedly the evidence of its national character, in an entirely different way, as the language of its Orthodox tradition, the language in which the Gospels were written. In this context the church followed a strictly formal view of the language and usually was very critical towards any attempt to translate holy books into spoken language, demotic Greek included.

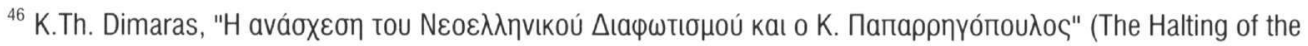

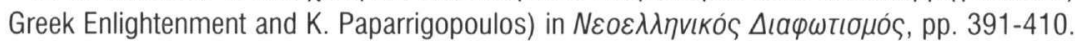

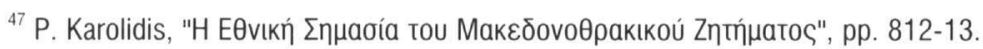
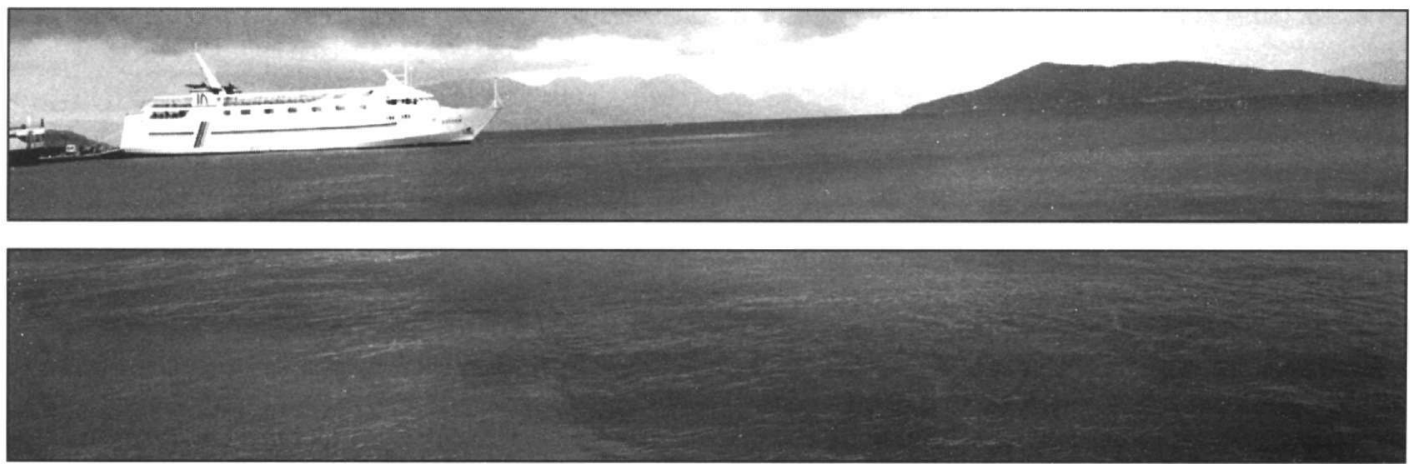